International Journal of Instruction e-ISSN: 1308-1470 • www.e-iji.net

Article submission code: 20210226074115

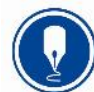

January $2022 \bullet$ Vol.15, No.1

p-ISSN: 1694-609X

pp. 293-310

Received: 26/02/2021

Revision: 23/06/2021
Accepted: 17/07/2021

OnlineFirst: 24/10/2021

\title{
Digital Competences of Vocational Instructors with Synchronous Online Learning in Next Normal Education
}

\section{Panita Wannapiroon}

Assoc. Prof., King Mongkut's University of Technology North Bangkok, Bangkok, Thailand,Panita.w@fte.kmutnb.ac.th

\section{Prachyanun Nilsook}

Prof., King Mongkut's University of Technology North Bangkok, Bangkok, Thailand, Prachyanun.n@fte.kmutnb.ac.th

\section{Jira Jitsupa}

Asst. Prof., corresponding author, Suan Dusit University, Bangkok, Thailand, jira_jit@dusit.ac.th

\section{Sakchai Chaiyarak}

Suan Dusit University, Bangkok, Thailand, sakchai_cha@dusit.ac.th

$$
\begin{aligned}
& \text { This research study was conducted with the following objectives: to develop; } \\
& \text { evaluate and; investigate the vocational instructors' satisfaction with the online } \\
& \text { instructional management developed using the synchronous online learning with } \\
& 2,233 \text { vocational instructors from the Office of the Vocational Education } \\
& \text { Commission, Ministry of Education, from five regions of Thailand, namely the } \\
& \text { Central, the Northern, the Northeastern, the Southern, and the Eastern Regions and } \\
& \text { Bangkok. The research findings revealed that the vocational instructors' digital } \\
& \text { competence consisted of the following abilities: 1) analysis of course content; 2) } \\
& \text { application of video conference systems; 3) management of online classes; 4) } \\
& \text { management of online learning resources; 5) management of online learning } \\
& \text { activities; 6) development of tests; 7) development of instructional media; 8) } \\
& \text { development of instructional videos; 9) arrangement of active-learning activities; } \\
& \text { and 10) online evaluation and assessment of instruction. The vocational } \\
& \text { instructors' digital competence in online instructional management after the } \\
& \text { synchronous online learning was found to be significantly higher than before the } \\
& \text { learning, at the p-value rate of .01. Overall, 93.19\% of the vocational instructors } \\
& \text { were reported to pass the evaluation of online instructional management. The } \\
& \text { vocational instructors were found to be satisfied with their own digital competence } \\
& \text { in online instructional management at the highest level. }
\end{aligned}
$$

Keywords: digital competency, next normal education, synchronous online learning, vocational instructors, learning

Citation: Wannapiroon, P., Nilsook, P., Jitsupa, J., \& Chaiyarak, S. (2022). Digital competences of vocational instructors with synchronous online learning in next normal education. International Journal of Instruction, 15(1), 293-310. https://doi.org/10.29333/iji.2022.15117a 


\section{INTRODUCTION}

The rapid growth of computer technology has resulted in an increase in online instruction and its application in education and research design for instructional development around the world ( $\mathrm{Li}$ et al., 2018). The number of online programs, such as Massive Open Online Courses )MOOCs(, for instruction on a network system has also dramatically increased and expanded. The online instructional model with instructor-learner interactions, as virtual cooperative classroom learning, was designed and developed to effectively promote online learning (Zhang et al., 2019). The online learning platforms are based on the concept of constructivist pedagogy, with the design of a screen which is attractively interactive with learners, with simple steps to learn everything. The platform plays a great role in online instruction, with a decrease in the limitations of learning time and place, and instructional resources and widespread interest among learners (Zheng \& Chen, 2020).

The rapid development of information technology and the internet has also caused educational institutes to apply some important policies and missions for educational reform and instructional management through the social network called online instruction (He, 2020). The internet has made worthwhile use of instruction, become a major pillar of sustainable development, and recorded online instruction in a more secure and economical way. Besides, it has also allowed instructors and learners to make contact through applications and chats. The parents can also contact their children's instructors to effectively check their children's progress from time to time. In this way, the rapid development of technology and digital media has become an important part of daily life and learning (Shukla et al., 2020).

Online instruction comprises some good points, as follows. Video clips can be recorded and later used for revising the lessons or improving the instructor's performance, without any limitations of time and place, with the help of internet networks. This enables learning from anywhere including at learners and instructors' personal locations (Ma et al., 2020). The situation with the spread of Covid-19 forced the governments in Europe and many other countries to close schools in their countries and instruct them to arrange online instruction (Gobbi \& Rovea, 2021). Out of this terrible situation of a global pandemic, it is fortunate that technology has been updated and applied with the social network systems, to provide instructors and learners with access to online instruction (Wang \& Xiong, 2020). This verifies that it is possible to use online instruction. Therefore, online instruction is one of the solutions to the problem of the spread of COVID-19, for pupils' learning, continuous instructional management, and school participation (Sripan \& Sujivorakul, 2020). The educational institutes' adjustment to this situation by designing instruction via internet systems and online programs is consequently the best current solution (Ping et al., 2020; Alessandro, 2018)

The quality and effectiveness of online instruction usually depend on students' learning situations, the arrangement of the online instruction atmosphere, learning targets and specifications, characteristics of learners in different classes, and instructional models of online instruction (Zou et al. 2020). The educational reforms of all countries worldwide have included more instruction and learning in the learning environment via social 
networks in the form of distance learning, so as to help instructors and learners perform instructional activities with interactions in the forms of messages, images, sounds, or video clips, synchronously (Zhang, 2020). To apply the technology with real-time online instruction, instructors need to study how to use the technology appropriately and to develop their ability to apply the technology for real-time online instruction through self-study, learning exchange with their colleagues, learning, and other means, so as to build up their understanding of new teaching skills quickly and to apply instructional innovations through instructional management )learning + technology + evaluation(. This promotes instructors' learning and self-development through modern technology, to provide their students with instruction which is useful and scientifically and technologically updated (Jieru et al., 2020).

Online instruction has shifted from traditional methods to new ones. The online instruction platform facilitates greater individual instructor-and-learner interaction. The digital instructional platform helps check learners' real-time participation, which enables each student's development. Appropriate selection of content and methods for online instruction better reflects the concept of learner-centred instruction. In addition, the instructor can also arrange discussions for cooperative learning and integrate the online instructional activities with various learning platforms (Alexandrescu \& Butnaru, 2020). The COVID-19 pandemic in Thailand caused educational institutes to adjust their instructional management with the help of online instruction, as in many countries throughout the world. In particular, the Office of the Vocational Education Commission )OVEC(, Ministry of Education, which has produced professional graduates as valuable assets to drive the business and industry sectors in Thailand, has issued a plan to prepare instructors and learners for instructional management through online systems in all institutes across the country, both public and private, under OVEC. Instructors and personnel in vocational education have developed their skills in instructional management through digital media. It has also been upgraded up to the level required for management. In doing this, OVEC, in collaboration with organisations in the public and private sectors, arranged training for 2,233 vocational instructors from all over the country through real-time online systems, to prepare them for online instruction and to promote both the online learning experience and their digital competence (OVEC, 2020).

\section{Objectives of Research}

1. To develop vocational instructors' digital competence in online instructional management using synchronous online learning;

2. To evaluate the instructors' digital competence in instructional management after the synchronous online learning;

3. To investigate the vocational instructors' satisfaction with online instructional management after the synchronous online learning. 


\section{Research Hypotheses}

1. The vocational instructors trained in online instructional management using synchronous online learning should have digital competence at a higher level than prior to their learning.

2. The vocational instructors trained in online instructional management using synchronous online learning should have digital competence at a high level.

3. The vocational instructors trained in online instructional management using synchronous online learning should be satisfied with the learning at a high level.

\section{Scope of Research}

The participants of this study were 2,500 vocational instructors applying for learning in online instructional management using synchronous online learning, out of which 2,233 instructors passed the evaluation of abilities and qualifications required for the online learning. The variables of this study consisted of one independent variable and two dependent variables. The independent variable was the synchronous online learning. The two dependent variables were the vocational instructors' digital competence and their satisfaction with the synchronous online learning.

\section{Research Instruments}

The test for evaluation of vocational instructors' digital competence in online instructional management with 20 items and 4 choices in each item. The evaluation form for 10 competencies in online instructional management: 1) analysis of course content; 2) application of video conference systems; 3) management of online classes; 4) management of online learning resources; 5) management of online learning activities; 6) development of tests; 7) development of instructional media; 8) development of instructional videos; 9) arrangement of active-learning activities; and 10) online evaluation and assessment of instruction. The evaluation form for the instructors' satisfaction with the synchronous online learning on a 5-Point Likert Scale with the choices of strongly disagree, disagree, neither agree nor disagree, agree, and strongly agree.

\section{Data Collection}

The vocational instructors attending the synchronous online learning performed a test for the evaluation of digital competence in online instructional management before the learning. The synchronous online learning was conducted for 30 hours in 5 days, to develop the vocational instructors' digital competence, according to the vocational instructors' development of online instructional management program. The instructors' digital competence was assessed with a focus on 10 competencies. The vocational instructors who attended the synchronous online learning did a test for the evaluation of digital competence in online instructional management after the training. The instructors' satisfaction with the synchronous online learning was evaluated with an evaluation form on a 5-Point Likert Scale. The data collected from the test, the 
evaluation form for the instructors' digital competence and the evaluation form for the instructors' satisfaction with the synchronous online learning, were analysed.

\section{Review of Literature}

\section{Next Normal Education}

The number of COVID-19 infections and casualties around the world is still continuously increasing. In the latest report from the World Health Organization, the total number of infected people around the world has reached almost 100 million, and many people have died (WHO, 2020). Although there was good news that many countries have begun to vaccinate some of their population, the number of vaccines is insufficient. So, it is still necessary to be careful, by avoiding visiting crowded areas and staying at home most of the time, as suggested by doctors and governments.

There have been serious effects on all areas of life, including business, finance, tourism, innovation, and technology. Social lives, behaviours, and people's ways of living have been changed from normal (United Nations, 2020b). In fact, there have been unexpected changes which have led to a Next Normal developing innumerable times, especially in terms of innovative and technological changes, like the launch of computer technology, communication technology and telecommunications, and mobile phone technology. Such changes always lead to both losses and gains, some incremental. However, the changes resulting from COVID-19 were so fast that they led to sudden interruption of activities. Business organisations and entrepreneurs needed their staff to work from home. The methods of buying and selling products changed from paying in cash to online purchases.

It has never previously been reported that most educational institutes temporarily stopped teaching at the same time; however, with this COVID-19 pandemic, all educational institutes at all levels, namely kindergarten, vocational and higher education, as well as all training programs, had to stop delivering their lessons in person for a while (United Nations, 2020a). They turned to arranging synchronous and asynchronous online instruction with digital technology, instead, to enable people to meet less and to stay apart from one another (Tria, 2020). As a result, instructors and learners who were not familiar with online instructional management using digital technology had to learn, practice, and build up their understanding of, and skills related to, this type of instruction in the most effective and efficient ways. These methods can replace, promote, or be integrated into the traditional instructional management in this particular situation, both during and after the COVID-19 pandemic.

In terms of theory, instructional management should rarely or never face any difficulties, or there should be a solution, due to the large amount of digital technology available to promote online instruction management. Prior to the pandemic, online instruction had already been introduced and approved. So far, over $80 \%$ of online instruction has been arranged (Wannaprapha et al., 2020). However, in practice, this kind of instruction needs real practice with tools, equipment, and machinery, particularly those provided at the educational institutes, especially for vocational students who need to learn from reallife practice with devices in their places of study or in factories (United Nations, 2020a; 
EDGE, 2020). In other words, this issue also needs to be revised and managed for further efficiency. The COVID-19 virus is considered to spread easily and quickly. If this continues, with no vaccines or medicine to rid it completely from the current world, digital technology will still be needed for work, life, and preparation for students' learning (Quilter-pinner \& Ambrose, 2020). Then, human beings will need to adjust themselves to the Next Normal and study and develop innovations to make their lives more normal.

\section{Vocational Education and Training}

Vocational Education and Training )VET( is an activity which is related to management of instruction and training, to develop students and train attendees to have the knowledge and ability required for their occupations. It is an important area of education in the country, for which there might be examinations to select students according to the skills required for each occupation. To achieve the management of vocational education, the curriculum, teaching materials, and workshops should be effective, and relevant organisations should allow the vocational students to join as interns.

Vocational education in Thailand is the next level of a three-year study for a vocational certificate )Voc. Cert.(, which focuses on areas of study other than general education. Having finished this level, the students may choose to study further for two more years to obtain a diploma or high vocational certificate )Dip./High Voc. Cert.(, or to continue either for the next two years or for four to five years in the selected faculty of any university at undergraduate level. The best reason for students to choose vocational education is that they can study in an area mainly focusing on the real practice of work in their particular profession (Dobricki et al., 2020). With just a vocational certificate, the students can obtain a job and the concepts of each curriculum are particularly designed for their future career. They gain knowledge, experiences, and an income during their studies. There are various choices of study programs for vocational skills, and they are in popular demand in the labour market. It is also an opportunity for higher education. As a result, over $47.8 \%$ of students have enrolled into vocational education and been vocationally trained in the EU after finishing Grade 9 (Cedefop, 2020).

In Thailand, the arrangement of vocational education is available in three models, normal vocational education, dual vocational education, and dual education. UNESCO has set up three major strategies for vocational education and training as guidelines for real practice: 1( fostering youth employment and entrepreneurship; 2( promoting equity and gender equality; 3( facilitating the transition to green economies and sustainable societies (UNESCO, 2016). However, the COVID-19 pandemic has greatly affected the instructional management for vocational education and training because it requires both the presentation of theories in class and real practice at a school workshop or relevant enterprises. Although theoretical instruction can be conducted online, real-life practice cannot really be effective because students need to learn from the real tools, equipment, and machinery. Therefore, many educational institutes have had to stop their instruction temporarily and reduce or remove tuition fees (Crisis et al., 2020), which may not be an effective solution due to the fact that learning should not suddenly cease or be delayed. 
Nevertheless, given the restrictions of social distancing, this seems to be the best decision in the circumstances.

\section{Digital Competence}

The challenge that most instructors in educational institutes are facing in the digital age is no longer related to possible applications of technology with instruction (Spante et al., 2018), but acknowledgement and decisions about when and how to use technology in education. The instructors should be prepared to integrate ICT with instructional management and should have the ICT skills required according to the Technological Pedagogical Content Knowledge )TPACK( (Falloon, 2020; Ge et al., 2018). The instructor's ICT competence is important for instruction because nowadays the focus is not only on lesson content, but also on use of technology (Redecker, 2017). The instruction which integrated with ICT is closely linked to TPACK (Y. Zhang \& Wang, 2019). Many educational policies have emphasised the use of digital technology to respond to future requirements. Professional instructors, in the future, will be key people who can implement the use of digital technology in instructional management and learner development (Engen, 2019). In terms of ICT use and the educational policy, which defines the vision and designs the ICT curriculum, the instructor needs to promote learning and improve their understanding of the educational policy. They must acquire more teaching skills with digital technology, and continuously practice using the skills required in alignment with changes. Hence, digital technology can be integrated and applied with instructional management effectively (Xiao et al., 2020).

The key message from the strategies of European development in 2020 is, "the new generation should be more flexible, creative and qualified as entrepreneurs" The new generation must be ready for the challenges in a working environment that has changed. They must have creative, logical, and critical thinking skills, problem-solving skills, leadership, responsibility and consideration. People with such skills will be in greater demand, not just in terms of science and technology. The educational institutes should consequently define "knowledge, creativity, responsibility for others and skills for the future”, as well as digital technology skills (Révészová, 2020). Since digital change really affects educational institutes, the instructional management should be continuously developed, to keep up with social and technological changes (JiménezHernández et al., 2020). The challenges which all educational institutes face result from digital changes and the specification of strategies for educational development which are related to the use of digital technology (Kamsker et al., 2020).

\section{Synchronous Online Learning}

Educational development in the form of online distance instruction has come to its peak during the COVID-19 pandemic. To reduce the spread of the virus, schools in most countries around the world were closed. However, education cannot stop. Therefore, many schools, colleges, and universities around the world have officially used modern curricula and study means with the help of online instruction in two models (Di Pietro et al, 2020). The first model of online instruction is synchronous learning, which is designed with technology and communication in the form of a VDO Conference. This 
requires the instructor and students to attend the class at the same time, so as to set up virtual classrooms with immediate evaluation. The other model is asynchronous learning, which is instruction emphasizing the learners' self-study using the instructor's teaching materials prepared in advance (Dhawan, 2020; Fidalgo et al., 2020; Aljaraideh, 2019). The teaching and learning method selected for this instructional model depends on the content in each lesson.

With online instructional tools, it is also possible to combine face-to-face learning and self-study learning in each weekly class, depending on the weekly classroom activities designed by the instructor. This is considered to be the development and transition of one teaching methodology to new techniques. Online distance learning is both the tool of and the challenge to improvement and promotion of students' learning processes, as well as the base of newer and better methods of knowledge management. The official use of online distance systems in training about educational processes has become significant to modern higher education institutes around the world (Oproescu et al., 2020). Online instruction has become necessary since the COVID-19 pandemic, with the basic structure developed to store and manage data securely for students' learning and to facilitate instructor-learner communication, the learners' access to the learning program from a distance, and the instructor's appropriate evaluation of students' learning (Alexandrescu \& Butnaru, 2020; Indrastyawati et al., 2020).

The concepts of online distance instruction management in universities are different from self-study online instruction management. In the former, students are advised by an instructor through a real-time learning process in which the instructor interacts with the students and arranges activities on the computer screen from a distance, via various platforms such as Zoom, Google Meet, Microsoft Teams, Cisco WebEx or Skype, which have different features. The similarities among these platforms are that the instructor and learners can present the learning content and the platform participants can see the presentations and interact through microphones and chat messages. The service platforms of Microsoft Office 365 for Education and Google G Suite for Education allow the users to sign into a single account but can use different services which facilitate online instruction (Singh \& Soumya, 2020). Zoom, one of the most popular tools for video conferences at present, has been used for online distance instruction because it is simple for users to join online meetings without registering into the meetings, but simply by using a Meeting ID gained from the meeting organiser. However, this may lead to problems of security and privacy; for example, verifying the right to sign in due to the availability of Zoom ID for everyone with no careful verification. The process of identity verification is not effective enough to prevent access by people who are not allowed to attend the meeting, which can lead to some difficulties (Mohanty \& Yaqub, 2020).

Online instructional management consists of the following basic concepts. First, it enables learners to access lesson content all the time, without a face-to-face meeting between the instructor and the learners in the classroom at the same time. This is different from normal classroom management. The instructor and all learners can communicate with one another and access the online lessons at their own convenience 
(Kuznekoff et al., 2019). The arrangement of cooperative learning activities helps develop learners' ideas and understanding better than when each learner studies alone. Besides, it also builds a relationship among the team members and exchanges ideas between them, so as to find the best solutions through the internet network as well as the computer hardware and software. Students also learn to search for knowledge themselves and, thus, avoid being led by the instructor. The instructor encourages them to acquire knowledge by providing some information or questions related to the knowledge, and then advising how to find the answer and giving them some feedback immediately. This helps the learners to become aware of their own abilities and to adjust their own direction, strategies, and performance appropriately. Online instruction is a way to provide an opportunity for everyone interested in studying, since learners do not need to go anywhere to study. They can study by themselves. However, online instructional management should focus more on the outcomes which will affect learners than on the application of technology with instructional management alone. Online instruction management is related to all instructional activities before, during, and after class, as in normal classroom instruction. The only difference is that everything needs to be adjusted to the context of online instruction (Jitsupa, 2020), as follows: preparation for instruction, during the lesson, and after the instruction.

\section{METHOD}

The training of vocational instructors' digital competence in managing online instruction with synchronous online learning employed the following steps.

Prior to the training, there was an opening for applications from vocational instructors from both public and private institutes under the Office of the Vocational Education Commission, Ministry of Education, from five regions, namely the Central, the Northern, the Northeastern, the Southern and the Eastern Regions and Bangkok. The researchers, in cooperation with the committee from the Office of the Vocational Education Commission, analysed the instructors' ability and selected 2,233 out of 2,500 instructors to join the training course with simple random sampling. Then, an online orientation was conducted to provide the trainees with information about the training, including the training rules, preparation, use of digital tools, and the learning outcomes as expected by the Office of the Vocational Education Committee. Later, the vocational instructors were assigned to take a pre-test with 20 test items before the training course began.

During the course, the training was conducted according to the vocational instructors' development program for online instructional management for five days, from 25 to 29 May 2020, for 30 hours. Then, the instructors' digital competence in online instructional management was assessed with 10 particular competencies: 1( analysis of course content; 2( application of video conference systems; 3( management of online classes; 4( management of online learning resources; 5( management of online learning activities; 6( development of tests; 7( development of instructional media; 8( development of instructional videos; 9 ( arrangement of active-learning activities; and 10( online evaluation and assessment of instruction. 
After the training, the vocational instructors were assigned to take a post-test comprising an online test of their digital competence with 20 test items and also to answer an evaluation form about their satisfaction with the training course.

All the results from the pre-tests and post-tests of the instructors' digital competence, the assessment forms of their particular competencies and the evaluation of their satisfaction with the training on online instructional management using synchronous online learning, were collected and analysed to find the values of mean, standard deviation )S.D.( and to compare the mean of the test result of digital competence with the dependent t-test.

\section{Data Collection}

The vocational instructors attending the synchronous online learning performed a test for the evaluation of digital competence in online instructional management before the training. The synchronous online learning was conducted for 30 hours in 5 days, to develop the vocational instructors' digital competence, according to the vocational instructors' development of online instructional management program. The instructors' digital competence was assessed with a focus on 10 competencies. The vocational instructors who attended the synchronous online learning did a test for the evaluation of digital competence in online instructional management after the learning. The instructors' satisfaction with the synchronous online was evaluated with an evaluation form on a 5-Point Likert Scale. The data collected from the test, the evaluation form for the instructors' digital competence and the evaluation form for the instructors' satisfaction with the synchronous online learning, were analysed.

\section{FINDINGS}

Out of 2,500 vocational instructors from five regions, namely the Central, the Northern, the Northeastern, the Southern and the Eastern Regions and Bangkok, who applied for the development of their digital competence in online instructional management, 2,233 instructors passed the evaluation of ability and were selected to join the training. The preliminary evaluation disclosed that the vocational instructors' digital competence consisted of 10 competencies, as follows: 1( analysis of course content; 2( application of video conference systems; 3( management of online classes; 4( management of online learning resources; 5( management of online learning activities; 6( development of tests; 7( development of instructional media; 8( development of instructional videos; 9( arrangement of active-learning activities; and 10( online evaluation and assessment of instruction.

The test scores of the vocational instructors' digital competence in online instructional management after the training were higher than the test scores before the training with the statistical significance at the level of 0.1 . The means of the digital competence evaluated before and after the training were 31.00 and 50.20, respectively, as shown in Table 1 below. 
Table 1

Test scores of vocational instructors' digital competence in online instructional management

\begin{tabular}{|c|c|c|c|c|c|c|}
\hline \multirow{3}{*}{ Group } & \multicolumn{6}{|c|}{ Test Scores Before and After Training } \\
\hline & \multicolumn{2}{|l|}{ Before } & \multicolumn{2}{|l|}{ After } & \multirow[b]{2}{*}{$\mathrm{t}$} & \multirow{2}{*}{ Sig } \\
\hline & Mean & S.D. & Mean & S.D. & & \\
\hline Vocational Instructors & 31.00 & 2.82 & 50.20 & 1.97 & -33.44 & $.000 *$ \\
\hline
\end{tabular}

$* * \mathrm{p}<.01$

According to the assessment results of the vocational instructors' digital competence in online instructional management after the synchronous online learning, 2,233 vocational instructors from public and private institutes under the Office of Vocational Education Commission joined the training. Of these, 2,081 instructors, or $93.19 \%$, passed the assessment of the vocational instructors' digital competence in online instructional management while 152 instructors, or $6.81 \%$ did not pass the assessment, as shown in Table 2 below.

Table 2

Assessment results of vocational instructors' digital competence in online instructional management after training

\begin{tabular}{llll}
\hline Results & Male & Female & Total \\
\hline Pass & 52.820 & 47.18 & $93.190 \%$ \\
\hline No Pass & 53.290 & 46.71 & $6.810 \%$ \\
\hline
\end{tabular}

The evaluation results of vocational instructors' satisfaction with the online instructional management training using synchronous online learning disclosed that the delivery of knowledge, the explanation of content, the use of the time allotted, the response to all questions in the training, the benefits gained and the application of knowledge with their work, were satisfying at the highest level, with the mean values of 4.51 , and standard deviation at 0.67 . This implied that the core vocational instructors were satisfied with the training at the highest level, as shown in Table 3 and Graph 1 below.

Table 3

Evaluation results of vocational instructors' satisfaction with online instructional management using synchronous online learning

\begin{tabular}{llll}
\hline \multirow{2}{*}{ List of Satisfaction Issues } & \multicolumn{3}{l}{ Level of Satisfaction } \\
\cline { 2 - 4 } & Mean & S.D. & Meanings \\
\hline Knowledge Delivery \& Content Description & 4.51 & 0.65 & highest \\
\hline Use of Time Allowed & 4.52 & 0.68 & highest \\
\hline Response to Questions in Training & 4.59 & 0.64 & highest \\
\hline Giving Examples for Discussion & 4.49 & 0.68 & high \\
\hline Time Spent on Training & 4.34 & 0.82 & high \\
\hline Training Model & 4.48 & 0.70 & high \\
\hline Knowledge Received & 4.49 & 0.66 & high \\
\hline Benefits Gained & 4.69 & 0.57 & highest \\
\hline Application of Knowledge with Work & 4.62 & 0.59 & highest \\
\hline Publication of Knowledge & 4.40 & 0.70 & high \\
\hline Total & 4.51 & 0.67 & highest \\
\hline
\end{tabular}


The vocational instructors' digital competence shown in figure 1.

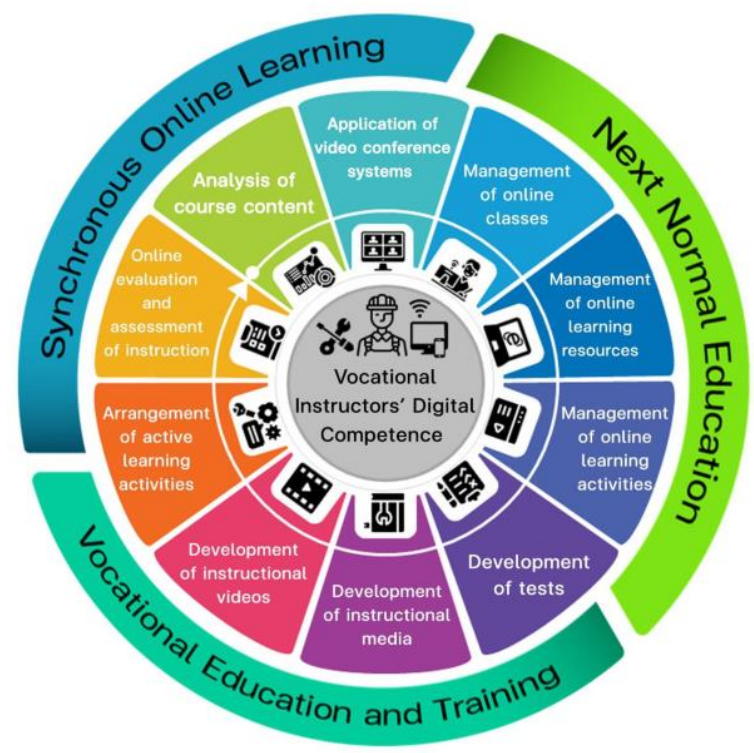

Figure 1

Vocational Instructors' Digital Competence

\section{CONCLUSION AND DISCUSSION}

Vocational instructors' digital competence in online instructional management consists of 10 competencies, as follows: 1( analysis of course content; 2( application of video conference systems; 3( management of online classes; 4( management of online learning resources; 5( management of online learning activities; 6( development of tests; 7( development of instructional media; 8( development of instructional videos; 9( arrangement of active-learning activities; and 10( online evaluation and assessment of instruction. The test results of the vocational instructors' digital competence in online instructional management after the training were higher than the test scores before the training with the statistical significance at the level of 0.1 . The means of the digital competence evaluated before and after the training were 31.00 and 50.20, respectively.

The vocational instructors'overall satisfaction with the online instructional management training using synchronous online learning was at the highest level, with the scores regarding the delivery of knowledge, the explanation of content, the use of the time allotted, the response to all questions in the training, the benefits gained, and the application of knowledge with their work, all at the highest level. The vocational instructors from the Northeastern and Eastern Regions and Bangkok were satisfied with the online instructional management training using synchronous online learning at the highest level, with a mean value of 4.51 , and a standard deviation of 0.67 . This implied 
that the core vocational instructors were satisfied with the online instructional management training at the highest level.

Digital competence is necessary for vocational instructors in a time (Wuttke et al., 2020; Rujira et al., 2020) when education has entered the Next Normal Period.The instructors should be able to manage their online instruction with both synchronous and asynchronous methods. Teaching is unlikely to return to normal instruction because learners are ready to study on their own through the use of online systems with the help of technology in the digital age as a tool for learning (Jitsupa \& Takamsan, 2021). In particular, vocational students are now living with the Next Normal conditions using ICT as a device for their daily life. Vocational instructors must have the competence to deal with the transition to the digital age (Benali et al., 2018). Technology is also essential for future life. Meanwhile, the degree of human contact is now decreasing due to the rise of technology use. Vocational instructors need to teach vocational skills and social skills with a basic knowledge of technology to their students. In addition, vocational instructors also need to possess the competence to integrate digital intelligence into future students' learning, too (Phunaploy et al., 2021).

\section{ACKNOWLEDGEMENTS}

Digital Competences of Vocational Instructors with Synchronous Online Learning in Next Normal is supported by a research grant from the Bureau of Personnel Competency Development, Office of Vocational Education Commission, Ministry of Education and King Mongkut's University of Technology North Bangkok.

\section{REFERENCES}

Alessandro, B. (2018). Digital skills and competence, and digital and online learning. TurinEuropean Training Foundation., 72. Retrieved from https://www.etf.europa.eu/sites/default/files/2018-10/DSC and DOL_0.pdf

Alexandrescu, A., \& Butnaru, G. (2020). An architecture of identity management and thirdparty integration for online teaching in a university. 850-855. https://doi.org/10.1109/icstcc50638.2020.9259652

Aljaraideh, Y. (2019). Massive Open Online Learning (MOOC) benefits and challenges: A case study in Jordanian context. International Journal of Instruction, 12(4), 65-78. https://doi.org/10.29333/iji.2019.1245a

Benali, M., Kaddouri, M., \& Azzimani, T. (2018). Digital competence of Moroccan teachers of English. International Journal of Education and Development Using Information and Communication Technology, 14(2), 99-120.

Cedefop. (2020). On the way to 2020: data for vocational education and training policies. Indicator overviews: 2019 update. In Luxembourg: Publications Office of the European Union. Cedefop research paper. https://doi.org/http://data.europa.eu/doi/10.2801/62708

Crisis, T. O. F., Foundations, B., Resilient, F. O. R., \& Educationtraining, V. (2020). 
VET in a time of crisis: Building foundations for resilient vocational education and training systems. (May).

Dhawan, S. (2020). Online Learning: A Panacea in the Time of COVID-19 Crisis. Journal of Educational Technology Systems, 49(1), 5-22. https://doi.org/10.1177/0047239520934018

Di Pietro, G., Biagi, F., Costa, P., Karpiński, Z., \& Mazza, J. (2020). The Likely Impact of COVID-19 on Education: Reflections based on the Existing Literature and Recent International Datasets. In Publications Office of the European Union, Luxembourg. https://doi.org/10.2760/126686

Dobricki, M., Evi-Colombo, A., \& Cattaneo, A. (2020). Situating Vocational Learning and Teaching Using Digital Technologies - A Mapping Review of Current Research Literature. International Journal for Research in Vocational Education and Training, 7(3), 344-360. https://doi.org/10.13152/IJRVET.7.3.5

EDGE. (2020). The impact of COVID-19 on education, A summary of evidence on the early impacts of lockdown. In The Edge Foundation. Retrieved from The Edge Foundation website: https://voxeu.org/article/impact-covid-19-education

Engen, B. K. (2019). Understanding social and cultural aspects of teachers' digital competencies. Comunicar, 27(61), 9-18. https://doi.org/10.3916/C61-2019-01

Falloon, G. (2020). From digital literacy to digital competence: the teacher digital competency (TDC) framework. Educational Technology Research and Development, 68(5), 2449-2472. https://doi.org/10.1007/s11423-020-09767-4

Fidalgo, P., Thormann, J., Kulyk, O., \& Lencastre, J. A. (2020). Students' perceptions on distance education: A multinational study. International Journal of Educational Technology in Higher Education, 17(1). https://doi.org/10.1186/s41239-020-00194-2

Ge, W., Han, X., \& Shen, X. (2018). Developing a validated instrument to measure teachers' ICT competencies for university teaching in a digital age. Proceedings - 2018 7th International Conference of Educational Innovation through Technology, EITT 2018, (2012), 101-105. https://doi.org/10.1109/EITT.2018.00028

Gobbi, A., \& Rovea, F. (2021). Distance teaching and teaching "as" distance. a critical reading of online teaching instruments during and after the pandemic. Teoria de La Educacion, 33(1), 71-87. https://doi.org/10.14201/TERI.23451

He, Y. (2020). Research on online teaching of music performance based on diversification and intelligence-take the online music teaching during the COVID-19 as an example. Proceedings - 2020 International Conference on E-Commerce and Internet Technology, ECIT 2020, 193-196. https://doi.org/10.1109/ECIT50008.2020.00050

Indrastyawati, C., Wu, Y. T., \& Sugito. (2020). The effects of the synchronous discussion and reflection system (SDRS) in perception of knowledge building and learning outcomes. International Journal of Instruction, 13(3), 699-710. https://doi.org/10.29333/iji.2020.13347a 
Jieru, D., Canjun, X., Mengzhou, Z., \& Xiying, Z. (2020). Dilemmas, Countermeasures and Enlightenment of Large-scale real-time online teaching in the Context of Epidemic situation. Proceedings - 2020 International Conference on Big Data and Informatization Education, ICBDIE 2020, 326-329. https://doi.org/10.1109/ICBDIE50010.2020.00082

Jiménez-Hernández, D., González-Calatayud, V., Torres-Soto, A., Mayoral, A. M., \& Morales, J. (2020). Digital competence of future secondary school teachers: Differences according to gender, age, and branch of knowledge. Sustainability (Switzerland), 12(22), 1-16. https://doi.org/10.3390/su12229473

Jitsupa, J. (2020). Online teaching and learning management vocational teacher skills development project. Bangkok, Thailand: Office of Vocational Education Commission, Ministrt of Education.

Kamsker, S., Janschitz, G., \& Monitzer, S. (2020). Digital Transformation and Higher Education: A Survey on the Digital Competencies of Learners to Develop Higher Education Teaching. International Journal for Business Education, 160(April), 22-41.

Kuznekoff, J. H., Munz, S. M., \& Titsworth, S. (2019). Online Learning. In Mobile Devices and Technology in Higher Education (Vol. 12, pp. 58-65). https://doi.org/10.4324/9780429355097-7

Li, L., Chen, Y., Li, Z., Li, D., Li, F., \& Huang, H. (2018). Online virtual experiment teaching platform for database technology and application. 13th International Conference on Computer Science and Education, ICCSE 2018, (Iccse), 437-440. https://doi.org/10.1109/ICCSE.2018.8468849

Ma, L., Bai, H., Dai, Q., \& Wang, H. (2020). Practice and thinking of online teaching during epidemic period. 15th International Conference on Computer Science and Education, ICCSE 2020, (Iccse), 568-571. https://doi.org/10.1109/ICCSE49874.2020.9201803

Mohanty, M., \& Yaqub, W. (2020). Seamless authentication for online teaching and meeting. Proceedings - 2020 IEEE 6th International Conference on Multimedia Big Data, BigMM 2020, 120-124. https://doi.org/10.1109/BigMM50055.2020.00026

Oproescu, M., Plaiasu, A. G., Niculescu, I., \& Nicolae, V. (2020). The challenges of the online teaching process - A short review. Proceedings of the 12th International Conference on Electronics, Computers and Artificial Intelligence, ECAI 2020. https://doi.org/10.1109/ECAI50035.2020.9223204

OVEC. (2020). Project of training for developing vocational teacher skills in online teaching and learning management. Bangkok: Office of the Vocational Education Commission, Ministry of Education.

Phunaploy, S., Nilsook, P., \& Nookhong, J. (2021). Effects of AL-MIAP-based Learning Management to Promote Digital Intelligence for Undergraduate. Multidisciplinary Journal for Education, Social and Technological Sciences, 8(1), 13. 
https://doi.org/10.4995/muse.2021.14048

Ping, Z., Fudong, L., \& Zheng, S. (2020). Thinking and practice of online teaching under COVID-19 Epidemic. Proceedings of 2nd International Conference on Computer Science and Educational Informatization, CSEI 2020, 165-167. https://doi.org/10.1109/CSEI50228.2020.9142533

Quilter-pinner, H., \& Ambrose, A. (2020). THE 'NEW NORMAL' THE FUTURE OF EDUCATION AFTER COVID-19. Retrieved from https://www.ippr.org/research/publications/the-new-normal

Redecker, C. (2017). European framework for the digital competence of educators: DigCompEdu. In Publications Office of the European Union. https://doi.org/10.2760/159770

Révészová, L. (2020). How to educate students for the future? 2020 43rd International Convention on Information, Communication and Electronic Technology (MIPRO), 570-575. https://doi.org/10.23919/MIPRO48935.2020.9245343

Rujira, T., Nilsook, P., \& Wannapiroon, P. (2020). Synthesis of vocational education college transformation process toward high-performance digital organization. International Journal of Information and Education Technology, 10(11), 832-837. https://doi.org/10.18178/ijiet.2020.10.11.1466

Shukla, A., Paid, N., Tanwar, S., Sadoun, B., \& Obaidat, M. S. (2020). BDoTs: Blockchain-based Evaluation Scheme for Online Teaching under COVID-19 Environment. Proceedings of the 2020 International Conference on Computer, Information and Telecommunication Systems, CITS 2020, 19-23. https://doi.org/10.1109/CITS49457.2020.9232480

Singh, R., \& Soumya, A. (2020). Updated comparative analysis on video conferencing platforms- Zoom, Google Meet, Microsoft Teams, WebEx Teams and GoToMeetings. EasyChair: The World for Scientists, 1-9.

Spante, M., Hashemi, S. S., Lundin, M., \& Algers, A. (2018). Digital competence and digital literacy in higher education research: Systematic review of concept use. Cogent Education, 5(1), 1-21. https://doi.org/10.1080/2331186X.2018.1519143

Sripan, T., \& Sujivorakul, C. (2020). Variables that influence the intention to persist in vocational education. International Journal of Instruction, 13(2), 17-32. https://doi.org/10.29333/iji.2020.1322a

Tria, J. Z. (2020). The COVID-19 Pandemic through the Lens of Education in the Philippines: The New Normal. International Journal of Pedagogical Development and Lifelong Learning, 1(1), 1-4. https://doi.org/10.30935/ijpdll/8311

UNESCO. (2016). Strategy for Technical and Vocational Education and Training (TVET). United Nations Educational, Scientific and Cultural Organization, 1-15. https://doi.org/10.1007/978-3-319-95870-5_300263 
United Nations. (2020a). Policy Brief: Education during COVID-19 and beyond. In United Nations. https://doi.org/10.24215/18509959.26.e12

United Nations. (2020b). The Impact of COVID-19 Pandemic on Trade and Development Transitioning to a New Normal. In Transnational Corporations. Geneva: United Nations.

Wang, Z. J., \& Xiong, S. J. (2020). The operation of smart online teaching of college english on the basis of the advanced technology of computer and information in vocational colleges. Proceedings - International Conference on Artificial Intelligence and Electromechanical Automation, AIEA 2020, 7-11. https://doi.org/10.1109/AIEA51086.2020.00009

Wannaprapha, T., Wutthiwan, W., \& Rukrermwong, J. (2020). Educational Technology with New Normal in Education. Journal of Humanities and Social Sciences Nakhon Phanom University, 10(3), 124-134.

WHO. (2020). COVID-19 Weekly Epidemiological Update. World Health Organization, (November), 1;4. Retrieved from https://www.who.int/docs/defaultsource/coronaviruse/situation-reports/20201012-weekly-epi-update-9.pdf

Wuttke, E., Seifried, J., \& Niegemann, H. (2020). Vocational Education and Training in the Age of Digitization, Challenges and Opportunities. In Barbara Budrich Publishers (4th ed.). https://doi.org/DOI 10.3224/84742432

Xiao, Z., Chu, X., Wu, Z., \& Zhang, Y. (2020). The Difference Evaluation of the ICT Competency to University Teachers from Two Perspectives in the Era of Mobile Internet. Proceedings - 2020 International Symposium on Educational Technology, ISET 2020, 243-245. https://doi.org/10.1109/ISET49818.2020.00060

Zhang, S. (2020). Development and forecast analysis of english network teaching aid platform under B/S technology framework. Proceedings - 2020 12th International Conference on Measuring Technology and Mechatronics Automation, ICMTMA 2020, 68-71. https://doi.org/10.1109/ICMTMA50254.2020.00023

Zhang, W., Chen, W., Zhao, H., \& Wang, R. (2019). Research on teaching presence evaluation indexes of online course. Proceedings - 10th International Conference on Information Technology in Medicine and Education, ITME 2019, 481-484. https://doi.org/10.1109/ITME.2019.00113

Zhang, Y., \& Wang, Y. (2019). Empirical study on the influencing factors of ICT-TPCK vocational teachers in higher education. Proceedings - 2019 8th International Conference of Educational Innovation through Technology, EITT 2019, 137-141. https://doi.org/10.1109/EITT.2019.00034

Zheng, Y., \& Chen, Y. (2020). Construction and implementation of blended teaching ecology based on cloud class. Proceedings of 2 nd International Conference on Computer Science and Educational Informatization, CSEI 2020, 292-295. https://doi.org/10.1109/CSEI50228.2020.9142492 
Zou, X., Wang, X., \& Hu, Y. (2020). Design of online teaching for network security technology under epidemic situation. Proceedings of 2 nd International Conference on Computer Science and Educational Informatization, CSEI 2020, 20-23. https://doi.org/10.1109/CSEI50228.2020.9142539 